\section{DISTRIBUTION OF INSECT IN PROTECTED FOREST AREA IN AMBON CITY}

\author{
W.S. Pinoa \\ Geography Departement, Faculty of Teacher Training \\ and Education, \\ Pattimura University, Indonesia \\ Fransina S. Latumahina \\ Forestry Department, Agriculture Faculty, Pattimura \\ University, Indonesia
}

Email Corespondence : fransina.latumahina@yahoo.com

\begin{abstract}
Insects are the dominant group of organisms and act as indicators of biodiversity, ecosystem health, and landscape degradation. The research objective was to determine the spread of insects in the Mount Nona Ambon Protected Forest. The research was conduct in January - March 2020 using Pitfall traps, light traps, Sweep nets, Bait traps, namely detergent, sugar solution and tuna fish. The research was carried out in 2 ha as many as five lanes with a systematic inventory sampling method where the length of the line was 100 meters, $20 \mathrm{~m}$ wide and $20 \mathrm{~m}$ spacing between lanes. The analysis use descriptively quantitative by calculating the Diversity Index $\left(\mathrm{H}^{\prime}\right)$ of Shannon Winner, Abundance Index (K), Dominance Index (C) and Evenness Index. The results of the study found 4063 individuals, 13 species in five orders. The Hymenoptera order dominated the spread of insects in the protected forest of Mount Nona, the Formicidae family with the smallest number of 12 individuals, namely Isodontia auripes from the order Hymenoptera family Sphecidae, and the largest number of them was Anoplolepis gracilipes with 401 individuals from the order Hymenoptera family Formicidae. The difference in insects' spread in the observation path is thought to be caused by differences in microclimate, altitude, vegetation cover, insect movement, light intensity and food availability.
\end{abstract}

Keywords : Insects, Diversity, ecosystem health, Ambon

\section{INTRODUCTION}

Insects play an essential role in the forest ecosystem as pollinators, pollinators, natural enemies of insect pests, decomposers, decomposers, animal protein foodstuffs, traded, fishing bait, honey bees and food sources [1]. The number of insects in Indonesia is approximately 250,000 species, or about $14 \%$ of all biota in Indonesia [2] Insects have the largest number of species, namely as much as $3 / 4$ per cent of all animal species on earth. [3]. Insects are Arthropods whose bodies into the head, chest and abdomen; the head has one pair of antennae, and the chest with three pairs of legs usually has one or two pairs of wings on the adult level. [4]. Insects can survive in various habitats, have a high reproductive capacity, the ability to eat different types of food, and save themselves from their enemies. The spread of insects in the forest depends on environmental factors, where each type has suitability to a particular environment. Several factors influence the spread of insects, namely the ability to spread, habitat selection, air temperature, humidity, soil moisture, light intensity, rainfall, vegetation, and food availability. [5]. Insects are a part of biodiversity that must be preserved from extinction or decline in species diversity. Insects have ecological, endemic, conservation, educational, cultural, aesthetic, and economic values. Different gen diversity is insects, thought to be caused by differences in climate, season, altitude, and food type. Insects in the forest can act as bioindicators of forest health, where the presence of insects can illustrate the relationship between biotic and abiotic environmental factors. [6]. Mount Nona Ambon Protection Forest has the primary function of protecting life support systems, regulating water management, preventing flooding, controlling erosion, preventing seawater intrusion, and maintaining soil fertility. Damage to the protected forest of Mount Nona will impact reducing water flow, banners and erosion. Therefore, this research is fundamental to do to obtain information and data related to the level of diversity, abundance and distribution of insects 
in the protected forest of Mount Nona, Ambon City, because insects are one of the main components in protected forests, where insect diversity will be an indicator of the stability level of the protected forest

\section{RESEARCH METHODS}

The research was carried out in January - March 2020 in the Mount Nona Ambon Protected Forest and was continued with laboratory research to identify the insects found. The tools and materials used are a Pitfall trap, light trap, Sweep net, Bait trap, microscope, tweezers, glass bottles, papillote paper, tape measure, rope, label paper. Writing instruments, digital cameras, and books on Introduction to Insect Lessons [7], Acarology, Mites and Human Welfare (Woolley, 1988) and The Pests of Crops In Indonesia. [3] The materials used are $70 \%$ alcohol, water, detergent, sugar solution and tuna fish

\section{Research Procedure}

The research does on 2 ha in 5 lanes with a systematic inventory sampling method with a length of 100 meters, the width of $20 \mathrm{~m}$ and distance between lines of $20 \mathrm{~m}$. Harvesting insects using three methods of capture. During the daytime, pitfall traps are installed at a distance of 10 $\mathrm{m}$ in the lane, bait traps with tuna bait, and sugar solution installed at every $10 \mathrm{~m}$ distance. Pitfall traps to catch insects that live above ground for 24 hours. Sweep net (insect net) use to catch flying insects from 08.00 - 18.00 WIT. They were catching nocturnal insects using light traps at $18.00-22.00$ WIT, in the form of an emergency lamp as a light source hanging from a tree with a height of 1 meter from the ground. The insects found were identified up to the species level, while the unknown insects will be identified according to the key of insect determination.

\section{Data Processing}

The analysis used in the research is the descriptive quantitative manner by calculating the Diversity Index $(\mathrm{H} ')$ of Shanon-Wiener, the Abundance Index $(\mathrm{K})$, the
Dominance Index (C) and the Evenness Index according to Odum 1983 in Kurniawan et al., 2018.

\section{Species diversity}

The value of species diversity using the Shannon-Wiener $\left(\mathrm{H}^{\prime}\right)$ diversity index [8]

$$
H^{\prime}=-\sum_{i=1}^{n} \frac{n i}{N} \log \frac{n i}{N}
$$

\section{Evenness determination (E)}

Evenness determination of insect species uses the

Evenness (E) evenness index : [9]

$$
\mathrm{E}=\frac{\mathrm{H} \prime}{\operatorname{Ln}(\mathrm{S})}
$$

\section{Index dominance}

Insect dominance was determined using the Simpson's Dominance Index [9]

$$
\mathrm{C}=\sum\left(\frac{n i}{N}\right)^{2}
$$

\section{RESULTS AND DISCUSSION}

\section{Distribution of Insects in Protected Forests}

The study results found 4063 individuals, 13 species in five different orders, and Table 1 below.

Table 1. Insect Distribution in Research sites

\begin{tabular}{|c|c|c|c|c|}
\hline Line & $\begin{array}{c}\text { Number of } \\
\text { Individuals }\end{array}$ & $\begin{array}{c}\text { Number of } \\
\text { Types }\end{array}$ & $\begin{array}{c}\text { Number } \\
\text { of Ordo }\end{array}$ & $\begin{array}{c}\text { Number of } \\
\text { Family }\end{array}$ \\
\hline I & 625 & 7 & 4 & 5 \\
\hline II & 980 & 8 & 4 & 4 \\
\hline III & 646 & 7 & 3 & 3 \\
\hline IV & 651 & 8 & 3 & 5 \\
\hline V & 1161 & 13 & 5 & 9 \\
\hline Total & 4063 & & & \\
\hline
\end{tabular}


Table 2. Insect Distribution in Line one

\begin{tabular}{|l|c|l|l|}
\hline \multicolumn{1}{|c|}{ Types of insects } & \multicolumn{1}{|c|}{$\begin{array}{l}\text { Number of } \\
\text { Individuals }\end{array}$} & \multicolumn{1}{|c|}{ Ordo } & Family \\
\hline $\begin{array}{l}\text { Delichoderus } \\
\text { thoracicus }\end{array}$ & 102 & Hymenoptera & Formicidae \\
\hline Anoplolepis gracilipes & 401 & Hymenoptera & Formicidae \\
\hline Grillus sp. & 20 & Orthoptera & Grillidae \\
\hline $\begin{array}{l}\text { Oechophylla } \\
\text { smaragdina }\end{array}$ & 35 & Hymenoptera & Formicidae \\
\hline Graphium agamemnon & 21 & Lepidoptera & Papilionidae \\
\hline Agriocnemis pygmaea & 34 & Odonata & Coenagrionidae \\
\hline Isodontia auripes & 12 & Hymenoptera & Sphecidae \\
\hline \multicolumn{1}{|c|}{ Total Individuals } & 625 & & \\
\hline
\end{tabular}

Table 3. Insect Distribution in Line Two

\begin{tabular}{|l|c|l|l|}
\hline \multicolumn{1}{|c|}{ Types of insects } & $\begin{array}{l}\text { Number of } \\
\text { Individuals }\end{array}$ & Ordo & Family \\
\hline $\begin{array}{l}\text { Delichoderus } \\
\text { thoracicus }\end{array}$ & 133 & Hymenoptera & Formicidae \\
\hline $\begin{array}{l}\text { Anoplolepis } \\
\text { gracilipes }\end{array}$ & 312 & Hymenoptera & Formicidae \\
\hline $\begin{array}{l}\text { Neoconocephalus } \\
\text { robustus }\end{array}$ & 231 & Hymenoptera & Formicidae \\
\hline $\begin{array}{l}\text { Oechophylla } \\
\text { smaragdina }\end{array}$ & 56 & Hymenoptera & Formicidae \\
\hline Solenopsis Sp & 32 & Odonata & Libellulidae \\
\hline Aetriamanta gracilis & 45 & Odonata & Libellulidae \\
\hline $\begin{array}{l}\text { Neurothemis } \\
\text { ramburii }\end{array}$ & 69 & Lepidoptera & Papilionidae \\
\hline $\begin{array}{l}\text { Graphium } \\
\text { agamemnon }\end{array}$ & 980 & & \\
\hline \multicolumn{1}{|c|}{ Total Individuals } & & & \\
\hline
\end{tabular}

Table 4. Insect Distribution in Line three

\begin{tabular}{|l|c|l|l|}
\hline \multicolumn{1}{|c|}{ Types of insects } & $\begin{array}{l}\text { Number of } \\
\text { Individuals }\end{array}$ & Ordo & Family \\
\hline $\begin{array}{l}\text { Delichoderus } \\
\text { thoracicus }\end{array}$ & 302 & Hymenoptera & Formicidae \\
\hline $\begin{array}{l}\text { Graphium } \\
\text { agamemnon }\end{array}$ & 23 & Lepidoptera & Papilionidae \\
\hline $\begin{array}{l}\text { Neurothemis } \\
\text { ramburii }\end{array}$ & 33 & Odonata & Libellulidae \\
\hline $\begin{array}{l}\text { Oechophylla } \\
\text { smaragdina }\end{array}$ & 210 & Hymenoptera & Formicidae \\
\hline Solenopsis Sp & 18 & Hymenoptera & Formicidae \\
\hline $\begin{array}{l}\text { Neurothemis } \\
\text { fluctuans }\end{array}$ & 23 & Odonata & Libellulidae \\
\hline Aetriamanta gracilis & 37 & Odonata & Libellulidae \\
\hline Total Individuals & 646 & & \\
\hline
\end{tabular}

Table 5. Insect Distribution in Line Four

\begin{tabular}{|l|c|l|l|}
\hline \multicolumn{1}{|c|}{ Types of insects } & $\begin{array}{c}\text { Number of } \\
\text { Individuals }\end{array}$ & \multicolumn{1}{|c|}{ Ordo } & \multicolumn{1}{|c|}{ Family } \\
\hline Delichoderus thoracicus & 198 & Hymenoptera & Formicidae \\
\hline Graphium Agamemnon & 43 & Lepidoptera & Papilionidae \\
\hline Abia lonicerae & 33 & Hymenoptera & Cimbicidae \\
\hline $\begin{array}{l}\text { Oechophylla } \\
\text { smaragdina }\end{array}$ & 234 & Hymenoptera & Formicidae \\
\hline Solenopsis $S p$ & 76 & Hymenoptera & Formicidae \\
\hline $\begin{array}{l}\text { Apis nigrocincta } \\
\text { Agriocnemis femina }\end{array}$ & 23 & Hymenoptera & Apidae \\
\hline Total Individuals & 651 & Odonata & Caenagrionidae \\
\hline
\end{tabular}

Table 6. Insect Distribution in Line Five

\begin{tabular}{|c|c|c|c|}
\hline Types of insects & $\begin{array}{l}\text { Number of } \\
\text { Individuals }\end{array}$ & Ordo & Family \\
\hline Delichoderus thoracicus & 309 & Hymenoptera & Formicidae \\
\hline Anoplolepis gracilipes & 321 & Hymenoptera & Formicidae \\
\hline Sphex pensylvanica & 23 & Hymenoptera & Sphecidae \\
\hline Aetriamanta gracilis & 44 & Odonata & Libellulidae \\
\hline Helopeltis sp. & 32 & Hemiptera & Miridae \\
\hline $\begin{array}{l}\text { Oechophylla } \\
\text { smaragdina }\end{array}$ & 235 & Hymenoptera & Formicidae \\
\hline Solenopsis $S p$ & 23 & Hymenoptera & Formicidae \\
\hline Epicauta lemniscata & 33 & Coleoptera & Meloidae \\
\hline Heterotrigona itama & 24 & Hymenoptera & Apidae \\
\hline Graphium agamemnon & 29 & Lepidoptera & Papilionidae \\
\hline Coenonympha dorus & 23 & Lepidoptera & Nymphalidae \\
\hline Rhinocypha monochroa & 22 & Odonata & $\begin{array}{l}\text { Chlorocypida } \\
\mathrm{e}\end{array}$ \\
\hline Sphex pensylvanica & 43 & Hymenoptera & Sphecidae \\
\hline Total Individuals & 1161 & & \\
\hline
\end{tabular}

The identification results in line one and two found the type of ant with the highest number of individuals is Anoplolepis gracilipes from the order Hymenoptera, family Formicidae 401 and 312 individuals. Anoplolepis gracilipes (Figure 1) is often nick named is yellow crazy ant because of its yellow (or reddish) colour and very chaotic movements during activity. This species has long legs, and the antennae move quickly while following a narrow foraging trail. These ants can dominate food sources and can forage on the soil surface and plants and become predators of the order Hemiptera, quickly taking sugar solutions during feeding. Field findings found Anoplolepis gracilipes and Dolichoderus thoracicus, and Oecophylla smaragdina prey on mealybugs that attack Salawaku Teak leaves in protected forests. The presence of Anoplolepis gracilipes ants in the ecosystem will hurt the entire protected forest ecosystem. The interactions that occur there can disturb the balance of the habitat and cause the elimination of other species that inhabit protected forests. A. gracilipes likes the added sugar solution and tuna fish, even seen some other tails use grass vegetation to become food. Protein-rich diets are necessary for the reproduction of queens. [10], where as carbohydrates are required to grow larvae and workers. Besides, A. gracilipes is also often found in symbiosis with fleas which can provide honeydew as a carbohydrate source. Carbohydrate supply may play an essential role in the successful invasion of A. gracilipes [11]. Observations show that A. gracilipes is more frequently found in paths that tend to be humid (micro temperature about $25^{\circ} \mathrm{C}$ ) and does not get direct sunlight, such as under teak ( Tectona grandis, 
Salawaku ( Paraserianthes falcataria) Tusam ( Pinus merkusii Jung et de Vriese), under piles of dry leaves, in root cavities and plant stems. Bamboo and under piles of rubbish and rotting logs. The identification results in lines three to five found the type of ant with the highest number of individuals, namely Delichoderus thoracicus from the order Hymenoptera, family Formicidae 302, 198 individuals and 309 individuals.

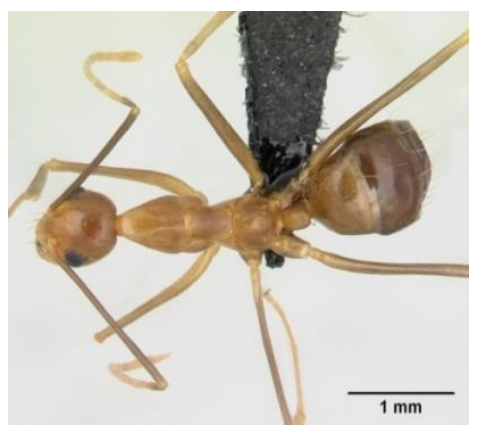

Figure 1. Anoplolepis gracilipes (https://www.antwiki.org)

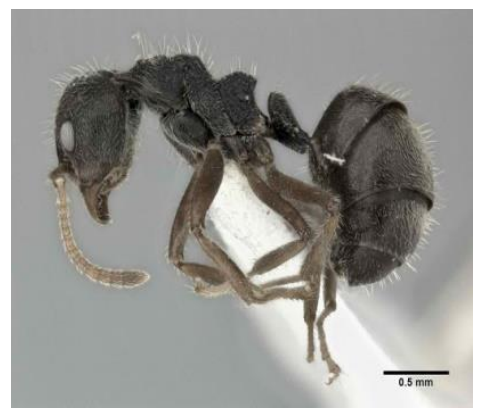

Figure 2. Delichoderus thoracicus (https://www.antwiki.org)

Delichoderus thoracicus has a massive number of individuals, which at the time of the study found worker ants with a length of 4.3 - 4.5 millimetres, legs brown, thoracic reduces, has no wings, the front of the abdomen shrinks with one dorsal protrusion, the antennae are brown and are of the geniculate type, i.e. the first segment is elongated and the second is short at an angle to the first. Worker ants have stingers, strong jaws, and glands that produce formic acid, which serves as a means of defence against enemies and to protect themselves. [12]. At the time of the study, 120 individuals were found among the leaves of Acacia (Acacia mangium), 25 on the trunk of the Tusam tree (Pinus merkusii Jung Et De Vriese) and the rest on the leaves and fruit of the Cocoa / Chocolate tree (Theobroma cacao). This type likes the sugar solution installed because it is a source of carbohydrates that will be stored in the form of fat to spur growth. This species likes the small insects in some orchids (Dendrobium $s p$ ) and sunflowers (Helianthus annuus) found in protected forests.

\section{Species Diversity, Evenness and Richness}

The value of species diversity, evenness, species richness and dominance of insect species in the location available in Table 7 .

Table 7. Species Diversity, Evenness, Species Richness and Dominance of Insects

\begin{tabular}{|c|c|c|c|}
\hline $\begin{array}{c}\text { Species } \\
\text { Diversity }\end{array}$ & $\begin{array}{c}\text { Evenness of } \\
\text { type }\end{array}$ & $\begin{array}{c}\text { Richness of } \\
\text { Insects }\end{array}$ & $\begin{array}{c}\text { Dominance } \\
\text { Index }\end{array}$ \\
\hline 0.92 & 0.65 & 3.56 & 1.5 \\
& & & \\
\hline
\end{tabular}

The index of insect species diversity in protected forests is low so that it is an indication that the productivity and stability in the protected forest area of Mount Nona are very low with poor environmental conditions so that insects are not interested in doing activities and even make nests in the protected forest area of Mount Nona Ambon. Diversity index unites species richness and evenness in one value [13]. Insect diversity can express community structure because insect diversity can produce stability in the protected forest of Mount Nona. After all, it is related to the ecological centre. The abundance of insects in Mount Nona's protected forest is thought to be influenced by climatic factors, food availability, and levels of disturbance. However, in an ecosystem, insects can adapt to their environment and avoid very extreme conditions from an ecosystem. The average temperature and air humidity in the observation path reached 30 0C with $87 \%$ humidity which is also thought to affect the presence of 
insects, in line with the opinion that the presence of a type of insect in a habitat is influenced by environmental factors, including the ability of these insects to spread, habitat selection, air temperature conditions, humidity, soil moisture, light, rainfall, vegetation and food availability. [14] The insect population density can change over time; it can be very high or low at any given time. These changes can occur in large or small amounts or scales and increase or decrease at certain times in protected forests. The insect diversity index in physically controlled ecosystems tends to be low and high in natural ecosystems. Unlike natural ecosystems, the probability of diversity index values can be> 2 [15] The level of diversity of insect species has a vital role in stability in the protected forest ecosystem. [16]. The level of vegetation diversity in protected forests affects the insect population due to the change in land use in the Mount Nona Forest after the social conflict in Ambon City, where residents cleared the forest to be used as residential areas, gardens, offices and roads. The insects found in the Mount Nona Protection forest are thought to have played a role as pollinators, decomposers, predators (biological controllers) and parasitoids (biological controllers).

\section{CONCLUSION}

Insects are part of biodiversity that must be preserved from extinction and from decreasing species diversity. Insects have essential values, including ecological values, endemism, conservation, education, culture, aesthetics, and economics. The Hymenoptera order dominated the spread of insects in the protected forest of Mount Nona, the Formicidae family with the smallest number of 12 individuals, namely Isodontia auripes from the order Hymenoptera family Sphecidae, and the largest number of them was Anoplolepis gracilipes with 401 individuals from the order Hymenoptera family Formicidae. The difference in insects' spread in the observation path depends on microclimate, altitude, vegetation cover, insect movement, light intensity and food availability.

\section{REFERENCES}

[1] H. C. J. Godfray, O. T. Lewis, and J. Memmott, "Studying insect diversity in the tropics," Philos. Trans. R. Soc. B Biol. Sci., 1999.

[2] A. Aryoudi, M. Pinem, and M. Marheni, "INTERAKSI TROPIK JENIS SERANGGA DI ATAS PERMUKAAN TANAH (YELLOW TRAP) DAN PADA PERMUKAAN TANAH (PITFALL TRAP) PADA TANAMAN TERUNG BELANDA (SOLANUM BETACEUM CAV.) DI LAPANGAN," J. Agroekoteknologi Univ. Sumatera Utara, 2015.

[3] J. B. Hughes, G. C. Daily, and P. R. Ehrlich, "Conservation of insect diversity: A habitat approach," Conserv. Biol., 2000.

[4] C. Haaland, R. E. Naisbit, and L. F. Bersier, "Sown wildflower strips for insect conservation: A review," Insect Conservation and Diversity. 2011.

[5] W. W. Murdoch, F. C. Evans, and C. H. Peterson, "Diversity and Pattern in Plants and Insects," Ecology, 1972.

[6] N. Janz, S. Nylin, and N. Wahlberg, "Diversity begets diversity: Host expansions and the diversification of plant-feeding insects," $B M C$ Evol. Biol., 2006.

[7] C. a. Triplehorn, N. F. Johnson, and D. J. Borror, Study Of Insects. 2005.

[8] E. P. Odum, "The strategy of ecosystem development," Science (80-. )., 1969.

[9] H. T. Odum and B. Odum, "Concepts and methods of ecological engineering," in Ecological Engineering, 2003.

[10] P. Matos-Maraví et al., "An ant genus-group (Prenolepis) illuminates the biogeography and drivers of insect diversification in the IndoPacific," Mol. Phylogenet. Evol., vol. 123, no. November 2017, pp. 16-25, 2018. 
[11] F. Latumahina, M. Borovanska, Musyafa, Sumardi, N. S. Putra, and M. Janda, "Ants of Ambon Island - Diversity survey and checklist," Zookeys, vol. 472, pp. 43-57, 2015.

[12] R. Safe'i, F. S. Latumahina, E. Suroso, and Warsono, "Identification of durian tree health (Durio zibethinus) in the prospective nusantara garden wan Abdul Rachman Lampung Indonesia," Plant Cell Biotechnol. Mol. Biol., vol. 21, no. 42, 2020 .

[13] G. C. Varley and E. O. Wilson, "The Insect Societies," J. Anim. Ecol., 1974.

[14] J. W. Gooch, "Insect," in Encyclopedic Dictionary of Polymers, 2011.

[15] T. Schowalter, Insect Ecology. 2006.

[16] C. M.A Wattimena, F. Latumahina, and N. Khomsah Kartikawati, "Inventarisasi serangga dan tingkat kerusakan yang ditimbulkan pada tegakan jati (Tectona grandis LINN. F) di areal hutan tanaman rakyat (HTR) negeri Hila Kabupaten Maluku Tengah," J. Pemuliaan Tanam. Hutan, 2020. 